\author{
SAND79-0106C \\ NEAR-PIELD INTERACTIONS * \\ J. L. Rrumhanal and D. F. MeVey \\ Sandia Laborator le : * \\ Albuquerque, NM 87185 \\ February 1979 \\ SAND- $-79-0406 \mathrm{C}$ \\ DE82 011303
}

ABSTRACT

To approach the subfect of high level nuclear waste disposal in deep ocean sediments it is convenient to differentiate between processes oceuring in a near field environment, that region arbitrarily defined as lying between the canister surface and the maximum extent of the $100^{\circ} \mathrm{C}$ isotherm, and those which oecur at lower temperatures and beyond the influence of intense radiation. A varlety of considerations related to the chemistry of seawater-sediment mixtures suggests that atout $200^{\circ} \mathrm{C}$ is the maximun temperature advisable in the near field environment. Results of coupled fluld flow - thermal transport computer model Bhow the maximum convection rate adjacent to a conizter having uurface temperature of $200^{\circ} \mathrm{C}$ is $0,3 \mathrm{~m} / 100$ years, and that this velocity is halved with the passage of each thermal half Ilfe of the assumed waste form (30 yearg). Based on this convective model, it follows that compounds formed in the near field environment during the firat thousand years following emplacement would be restricted to a region lying within cwo meters of the canister surface.
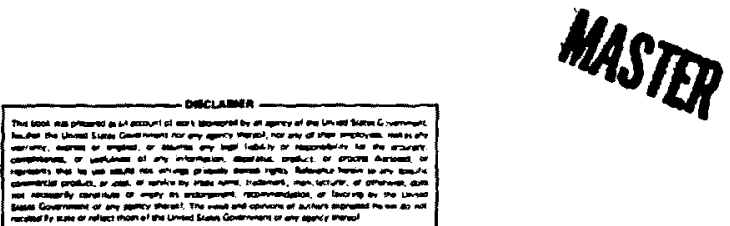

\footnotetext{
This work was supported by the U.s. Department of Energy under Contract Ar(29-1)-789.
}

-A U. B. Department of Energy facllity 
In assessing the feasibility of high level nuclear waste disposal in a deep sea environment, a number of questions have arisen pertaining to the changes that may be induced by heat and radiation in innediate proxinity to aste caniater. Unlike the various indurated rock types being considered in conjunction with land besed disposal options, the marine sediments presently being examined are categorized as unconsolidated clay. As such, they often contain in excess of oixty percent water by volume, have shear strengths leas than $29 \mathrm{kPa}$, and, with the exception of an occasional manganese nodule or ash layer, consiet of relatively homogeneous material. As presently envieioned, waste would be placed in a metal canioter end implanted to a depth of between thirty and one hundred meters in unconsolidated sediment. Ocean depth at the disposal site would be in excess of $5 \mathrm{~km}$.

Because of the unconsolidated nature of the sediment and short distance to the sediment-water interface, near field proceases have direct bearing on the ability of the sediment to retard radionuclide migration. Beyond this statement, a great many factors go into determining wat limits actually exist on the eyaten. This paper will first review a number of physical and chemical aspects which serve to constrain the maxinum adviable temperature and then present the results of a coupled fluld flow-thermal tzansport model for a geometry appropriate to a buried waste canister.

\section{CREHICAL IRTERACTIONS}

A number of general obeervatione way be unde regarding behavior of saltwater and seawater-sedinent mixtures at elevated tenperatures and preseures. Hydrontatic pressures presently envisioned ror seabed waste diaposal (50-60 MPa, 500-600 bara) exceed the critical pressure of water. Thus bolifing in the usual context of a substantial discontinulty in water density. resulting from the transition from liquid to gas does not exist. Rather, the denelty of the seawater mixture decreases smoothly as temperature Increases (Flgure 1) unt1l a temperature, dependent on pressure and salt concentration, is reeched where the ixture oeparates Into two phases with different alt concentrations and densities 1 . This characterietle behavior of multicomponent eystend is show in Figure! for macl water aystem. Should the temperature be allowed to increase sufficlently, the density contract orieing from efther the density decrease sa e Eunction of temperature or phase separation could surve as mechanien to damage the sedient integrity or tranoport andicant and nuclides upward trom the canister. To avoid a phase ceparation, maxinum teaperatures should be leas than $175^{\circ} \mathrm{C}$. To avold a density decreves of core than twenty jorcent, the teaperature should reas in below about $300^{\circ} \mathrm{c}^{2}$. 


\section{Boiling of NoCl Solutions \\ (Sourirajon and Kennedy, 1962)}

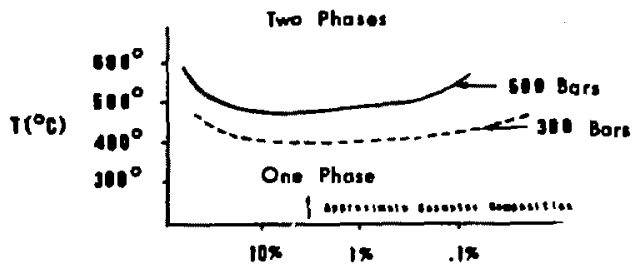

wt. $\$ \mathrm{NoCl}$

Figure IA

$$
\begin{aligned}
& \text { Density of .6m NaCl Solutions } \\
& \text { (Potter and Brown, 1973) }
\end{aligned}
$$

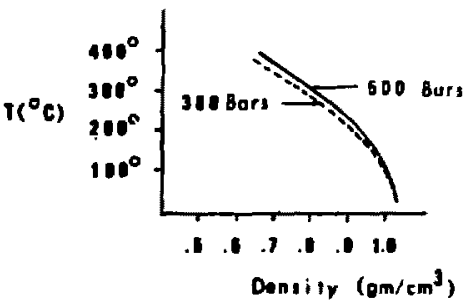

figure $1 B$ 
Although limiting temperatures to restrict the denaity change is an important consideration, an argument may be made that the axinum allowable tenperature should be still lower when one addreases chenical interactions. Laboratory experiments have shown that a sample of geawater drawn fron a mixture of five parts seawater to one part dry weight sediment contacted at $300^{\circ} \mathrm{C}$ and $50 \mathrm{MPa}$ for few hours may initially have a pH (reasured at $25^{\circ} \mathrm{C}$ ) as low as 2.9. After having been in contact with sediment for several months, the solution ph gradually increases to 4.0 (Table 1). The 1 ow $\mathrm{pH} 18$ the consequence of several chemical reactions which occur at varying rates. At temperatures above $250^{\circ} \mathrm{C}$ a magnes fum oxysulfate precipitates immediately leaving an excess of hydrogen ion in solution ${ }^{3}$. Somewhat slower are the reactions involving oxidation of organic material and incorporation of magneaium into silicate minerals. In the presence of marine sediments, however, these complex interactions also serve to further depress the pH. It is probable that the $\mathrm{pH}$ increase noted in Table 1 results from the gradual alteration of plagioclase feldspar to clay. 4 Quenched pH values of $3.3,3.9$ and 5.5 have been reported for seawater samples that have been heated to $270^{\circ} \mathrm{C}, 250^{\circ} \mathrm{C}$, and $200^{\circ} \mathrm{C}$, respectively at $5 \mathrm{mPa}{ }^{5}$ For samples of seawater that were filtered from seawater sediment mixtures at $200^{\circ} \mathrm{C}$ and 50 MPa and then cooled to room temperature, seyfried reports a pH of 5.2 after three days and 4.9 at the end of a week. It follows that at $200^{\circ} \mathrm{C}$ seawater gediment mixtures have the potential for supplying only a few percent of the hydrogen ion generated at $300^{\circ} \mathrm{C}$ or higher temperatures.

Acid conditions adjacent to a wate canister are, in general, undesirable. Corrosion of poteptial canister materials may increase in such an environmegt 5,6 as may the alteration rate of a wide varlety of giasses. $7,8,9$. Some perspective on the problem nay be gained by noting that in oxygenated seawater at $250^{\circ} \mathrm{C}\left(1750 \mathrm{ppa} \mathrm{O}_{2}\right.$ ) several metale (e.g. lead, 90-10 Cu-N1, and Hastelloy $(-276)$ have corrosion rates of $1 \mathrm{~mm} /$ year or less . At $^{\mathrm{s}}$ this rate roughiy three centimeters of material are reguired per thermal half iffe ( 30 yeara) of $h$ igh level waste and as the tenperature falls, markediy slower corrosion rates would be expected.

Radionuclides liberated into an acid environment way be relatively moblle. Sone of the elementa of concern tend to for insoluble hydraxides or be sorbed onto the fron and manganese hydroxides already present. Other radionuclióes may sorb onto the clays thenselves. Acid conditions may cerve to mitigate the effectivenese of all these retention wechaniems and, in fact, it has been found that seawater solutions in contact with clays at $300^{\circ} \mathrm{C}$ comboniy contaln greater concentratione of many trace lements than are found In seawater sediment mixtures at room temperature (Table 2). In 1ight of theae considerations, It ceana likely that by limiting the maximum temperature to about $200^{\circ} \mathrm{C}$ it is posalble to aignificantly improve barrier propertied of the near fleld enviranment over what would exist at higher temperstures. 
mble 1: Concentretices of dissolved aqueous spocies (ppo) in sewrater during reaction with ondirent at $300-\mathrm{C}, 500$ hars: Finor components.

(Seyfried and Jenecke, Seabed Annual Roport, 1978)

\begin{tabular}{|c|c|c|c|c|c|c|c|c|c|c|}
\hline ell & (Hr) & 래 & $\mathrm{CO}_{2}^{*}$ & $\mathrm{k}^{+}$ & $\mathrm{I}^{+}$ & $\mathrm{Ca}^{+2}$ & $\mathrm{Mg}^{+2}$ & $\mathrm{SiO}_{2}$ & $\mathrm{SO}_{4}=$ & $\mathrm{CI}^{-}$ \\
\hline $\begin{array}{l}0 \\
1 \\
2 \\
3 \\
4 \\
5 \\
6 \\
7 \\
0\end{array}$ & $\begin{array}{r}0 \\
6 \\
29 \\
81 \\
172 \\
455 \\
964 \\
1657 \\
2351\end{array}$ & $\begin{array}{l}8.2 \\
2.9 \\
2.85 \\
3.29 \\
3.50 \\
3.75 \\
3.85 \\
4.05 \\
5.52\end{array}$ & $\begin{array}{c}2510 \\
2200 \\
2090 \\
2110 \\
2180 \\
2246 \\
2440 \\
-\end{array}$ & $\begin{array}{l}10763 \\
11053 \\
11308 \\
11362 \\
11430 \\
11113 \\
11861 \\
11944\end{array}$ & $\begin{array}{r}399 \\
661 \\
939 \\
977 \\
1053 \\
996 \\
896 \\
771 \\
616\end{array}$ & $\begin{array}{r}412 \\
127 \\
144 \\
179 \\
214 \\
257 \\
293 \\
323 \\
1251\end{array}$ & $\begin{array}{r}1297 \\
663 \\
558 \\
456 \\
397 \\
268 \\
123 \\
72 \\
141\end{array}$ & $\begin{array}{r}<0.1 \\
1055 \\
1232 \\
1145 \\
1107 \\
1025 \\
983 \\
358 \\
336\end{array}$ & $\begin{array}{r}2734 \\
1306 \\
1648 \\
1454 \\
1182 \\
387 \\
1109 \\
991\end{array}$ & $\begin{array}{l}19375 \\
19345 \\
19467 \\
19476 \\
19700 \\
19431 \\
19561 \\
19511\end{array}$ \\
\hline
\end{tabular}

Tuble 2: Concentrations of trace and minor components (ppm)

\begin{tabular}{|c|c|c|c|c|c|c|c|c|c|}
\hline seplo & (Hre) & $\mathrm{Fe}^{+2}$ & $\mathrm{kn}^{+2}$ & B & Al & $2 n$ & Sr & $\mathbf{M}$ & Ba \\
\hline $\begin{array}{l}0 \\
1 \\
2 \\
3 \\
4 \\
5 \\
6 \\
7 \\
0\end{array}$ & $\begin{array}{r}0 \\
6 \\
29 \\
81 \\
172 \\
455 \\
964 \\
1657 \\
2351\end{array}$ & $\begin{array}{l}<0.01 \\
25.5 \\
54.2 \\
50.7 \\
43.0 \\
39.1 \\
41.0 \\
40.2\end{array}$ & $\begin{array}{l}<0.01 \\
367 \\
343 \\
334 \\
310 \\
302 \\
269 \\
226\end{array}$ & $\begin{array}{l}5.9 \\
21.3 \\
16.7 \\
17.6 \\
17.9 \\
17.5 \\
19.0 \\
18.7\end{array}$ & $\begin{array}{c}<0.01 \\
0.36 \\
0.09 \\
0.11 \\
0.17 \\
0.25 \\
0.25 \\
0.23\end{array}$ & $\begin{array}{r}<0.01 \\
8.55 \\
10.04 \\
10.84 \\
11.46 \\
11.89 \\
11.90 \\
11.11\end{array}$ & $\begin{array}{l}8.0 \\
2.95 \\
1.56 \\
2.60 \\
3.43 \\
4.95 \\
6.77 \\
7.68\end{array}$ & $\begin{array}{c}+0.01 \\
0.02 \\
0.53 \\
1.01 \\
.59 \\
0.75 \\
0.72 \\
-\end{array}$ & $\begin{array}{r}<0.01 \\
<0.09 \\
0.10 \\
0.25 \\
0.30 \\
0.43 \\
0.64 \\
1.41\end{array}$ \\
\hline
\end{tabular}

(-) Hot Amelrzed

(*) Assimes total exsolved gas phase as $\mathrm{CO}_{2}$

$Q=$ Quinched value at conclusion of experiment 
In order to assess the thermal and convective responses to waste emplacement in the seafloor, a coupled fluld flow thermal trangport model was run for inftial thermal loadings of $1.5,2.0$ and $3.0 \mathrm{kH}$ of 10 year $01 \mathrm{~d}$ high level waste in a three-meter long by $0.15 \mathrm{~m}$ radius canister. A temperature Independent sediment permeability of $10^{-13} \mathrm{~cm}^{2}$ was extracted from test datalo. Theragl conductivities were assumed to be those, fetermined to $4 \mathrm{co}^{\circ} \mathrm{C}$ on a sample of 1111 tic deep sea clay. II Details of the assumptions made in the computer program used for the analysis are isted. In Table 3.

Several aspects of the thermal modeling have bearing on expected conditions in the near fiela environment. The relationship between thermal loading and peak temperature at the canister surface is 1llustrated in Figure 2. It 18 apparent that if a maximum temperature of $200^{\circ} \mathrm{C}$ is allowed, a thermal loading of $1.3 \mathrm{kH}$ per canister is permisaible. This is equivalent to roughly forty percent of that expected of a borosilicate glass loaded with thirty weight percent ten year aged heavy metal oxides, or alternatively, to a baseline canister of spent fuel assemblies. Also shown In Figure 2 are maximum convective velocities as a function of canister thermal power. The maximum velocity occurs at about 2.0 years after emplacement for all three thermal loadings. Temperature and velocity histories for the three cases are typified by the curves given In Eigure $3 A$ and $3 B$ for the $2.0 \mathrm{kH}$ case. Both temperature and and velocity decay with a half life of about 30 yearg for the first 150 years and more slowiy after that.

It is apparent that with peak velocities and decay rates of the magnitude shown in Figures 2 and 38 that for a volume of convectively driven fluid to migrate 20 cm requires about 100 ysars and that at least ten times that long would be required for an adgftional $20 \mathrm{~cm}$. Many of the riseion products such as ${ }^{137} \mathrm{Cs}$ and $90_{\mathrm{Gr}}, 30.2$ and 28.9 yeare halt-11fe, respectively, would have decayed to Insignificant levela before the fluid migrated a meter. In fact, convection is so siow that diffusion chould preilominate in determining the exchange of materials in and out of the near fleld environient ${ }^{2}$. A second Implication of the extremely slow convection rate 18 that the primary mode of heat transfer is by conduction.

A Inal observation deale with the influence the near field environment $w 111$ have on aediments at greater diatances. hesune the case with the $2 \mathrm{~kW}$ initial thermal loading which results in a maximun tempirature of about $305^{\circ} \mathrm{C}$. Within about 17 yeers following emplectment, the caninter surface temperature wili have dropped to $200^{\circ} \mathrm{C}$ and $1 \mathrm{t}$ is probable that further acid generation will not occur. Because of the extrenely low velocitles over this time span, a negligible anount of water wil convect through regione in excess of $200^{\circ} \mathrm{C}$. It is also 


\section{TABRE III}

A COAPUTER CODE FOR ANALYSIS OF FLOA AND HEAT FRANSFER IN POFOUS MRDIA

\section{ASSUMPIONS}

Tro-Dimensional Geometries (Plane or nxtsymetric)

RIgld Porous Matrdx

Single Flutd, Single Phese, Incomprese1ble, Darey Flow

Bousinesq Approximetion

Fludd Inertin Erfects Neglected

Fuid and Matrix in Thermel Equilibrium

\section{FEATURES}

Finite Blenent Code

Transient or Steady Stute Analyolo

Variable Material Proparties

Anisotropic Mirix Miterials

\section{STATUS}

In Pinel Steges of Checkout 


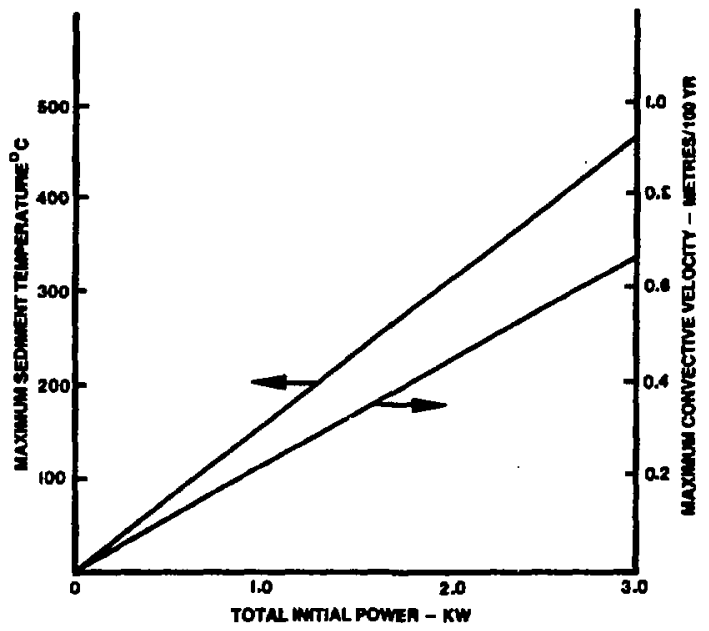

FIQURE 2 MAXMUM SEDIMENT TEMPERATURE AND

MAXMUM CONVECTIVE VELOCTTY AS A

FUACTION OF INITISL THERMAL POWER 


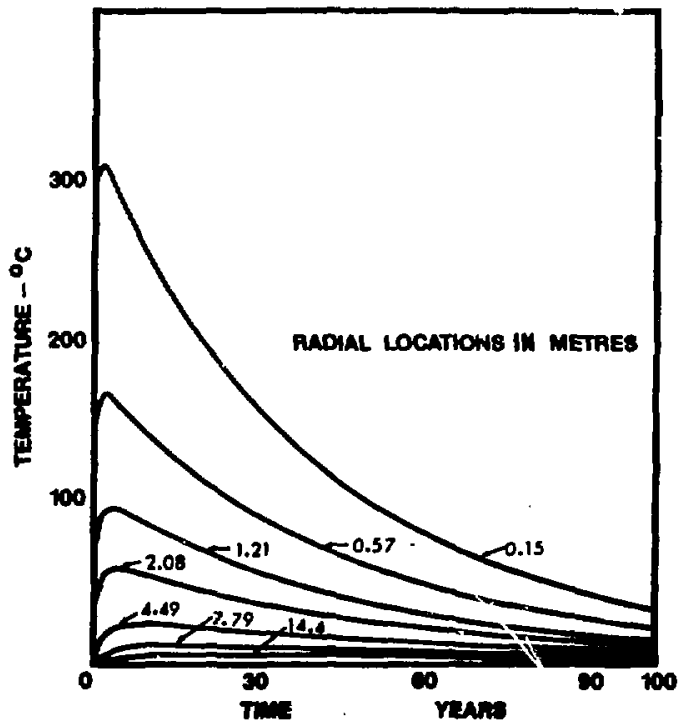

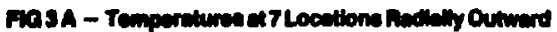

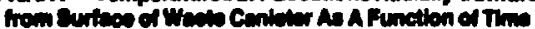




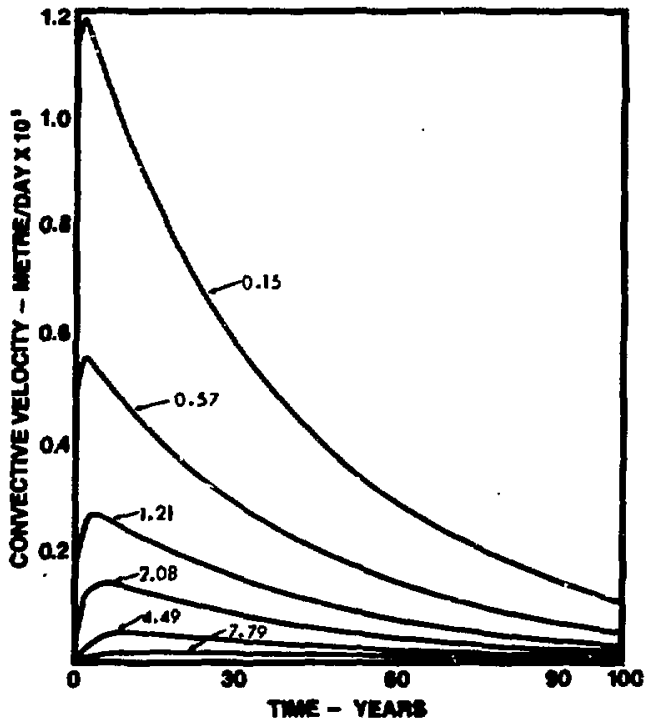

F10. 39 COMVETMV VILOCIVY AT S RADIAL LOCATICN

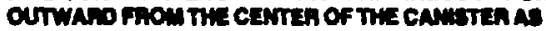
A Fuiction or Tris. 
predicted that only a miniscule amount of magnesfum can diffuse into this region to generate additional acidity. The total amount of acid generated may, therefore, be approximated from the volume of sediment heated above $200^{\circ} \mathrm{C}$ and the observation that a pl of 3 corresponds to the greatest hydrogen ion 1 iberation achieved in sediment seawater mixtures at $300^{\circ} \mathrm{C}$ (Table 1A). Sedinent volumes above $200^{\circ} \mathrm{C}$ may be estimated from the isotherm plots in pigures $4 \mathrm{~A}-\mathrm{C}$ and are $0.25 \mathrm{~m}^{3}, 0.80$ $\mathrm{m}^{3}$ and $4.5 \mathrm{~m}^{3}$ for the $1.5,2.0$ and $3.0 \mathrm{kH}$ power levels, respectively. It has been found experimentaliy that roughly 0.1 meg acid per gram of sediment are reguired to titrate a one to ten sediment-deionized water mixture from a pH of 8 to 5.13 It follows that only a cubic meter of unheated sediment would be required to neutralize all the acid generated during the thermal history of a canister, even when an extreme thermal loading of $3 \mathrm{kh}$ was assumed. Any radionuclides diffusing into the far field environment would goon encounter a pH characteristic of a normel bagic marine environment. The possibility does exist, however, for substantial local redistribution of radionuclides within the near field environment.

An argument can be made at this time that the near-field temperatures should not exceed roughly $200^{\circ} \mathrm{C}$. Within the assumptions of the thermal-fluid flow model it appears that a highly reactive environment will exist in the near field, but it is unlikely that radioisotopes with half-lives less than a century would persist long enough to be transported beyond the near-field environment. If the heating process is accompanied by marked changes in sediment properties, considerably greater convective transport could result. Processes may also exist which could transport the near-field environment in a mass to the sedinent-water interface. Buoyancy effects due to modest denaity differences and the localized reconcentration of heat produclng radioisotopes will receive particular attention in future atudies as will the conseguences of intense ganna radiation, both as they pertain to gediment properties and to the chenistry of the interatitial water. 




FG 4 - ISOTHEAM FLOTS SHOWNG MAXIMUM PENETAATION OF $200^{\circ} \mathrm{C}$ BOTHERM IWTO SEDINENT 
1. S. Souriragan and G. $C_{c}$ Kennedy, The System $\mathrm{H}_{2} \mathrm{O}-\mathrm{HaCl}$ at slevated Temperatures and Pressures", Am. J. Sc1., Vol. 260, pp 115-141, 1962.

2. R. W. Potter and D. L. Brown, U.S. Geol. Survey Open File Regort 75-636, 1973 .

3. J. I. Bischoff and $W$. E. Seyfrled, Hydrothermal Chenistry of Seawater from $25^{\circ} \mathrm{C}$ to $350^{\circ} \mathrm{C}, " \mathrm{An}$. J. Sc1, vol. 27B, pp 838-860, 1978 .

4. N. E. Seyfried, University of Minnesota, Dept, of Geology and Geophysics, Minneapolis, Minn. (Personal communication).

5. J. H. Braithwalte and $H$. A. Molecke, "Blgh-Level Haste Canister Corrosion studiea Pertinent to Geologic Isolation," Nuclear Haste Management and TechnologY, vol. 1 (1), 1979.

6. D. W. Shannon, "The Role of Chemlcal Components in Geothermal Brines on Corrosion," Paper 57, presented at Corrosion 78, NACE, Houston, Texas, March 6-10, 1979.

7. H. A. Rose et al.. Annual Report on the Character Ization of High Level Waste Glasses, PNL-2625, June 1978.

6. F. H. Dickson, "The Role of Rhyolite-Seawater Reactica in the Genesis of Kuroko Ore Degosits," Second International symposium on hater-Rock Interaction, Vol. IV, pp. I81-190, suguat 1977.

9. $\dot{w}$. E. Seyfried, Seawater-Basalt Interactlong from $25^{\circ}$.. $300^{\circ} \mathrm{C}$ and 1-500 Bacs: Inpllcations for the Origin of Submarine Metal-Bearing Bydrothermil Solutions and Regultation of Ocean Chenistry. PhD thesis, univeraity of Southern Cal1f.. Pebruary 1977.

10. A. J. S11va and D. I. Calnan, Geotechnical Aepecta of Subsurface seabed Dlsposal of HIgh-Level Radloactive Waste, Annual Progrese Report No. 5, Univergity of Rhode IaIand, PP 14-28, 19.

11. G. R. Hadiey, Division 5511, Sandia Laboratories, Albuquerque, Hew Hextco (personal communtcation).

12. Seabed Dlaposal Program Annual Report- Part I, JanuaryDecenber 1976, SAND77-1270, D. H. Talbert, ed., PP 37-43. IS77.

13. K. L. Erickson, Divigion 5812, sand1a Laboratoriea, Mlbuquerque, New Mexico (Personal communtcation). 